\title{
FRUIT PEELS: A STRONG NATURAL SOURCE OF ANTIOXIDANT AND PREBIOTICS
}

\author{
Ena Gupta1, Neha mishra², Pragya Mishra ${ }^{3}$ Abeer Shiekh $^{3}$, Karishma Gupta ${ }^{3}$, Priyanka singh ${ }^{3}$

\begin{abstract}
${ }^{1}$ Department of Home Science, Faculty of Science, University of Allahabad, Prayagraj, Uttar Pradesh, India ${ }^{2}$ Sam Higginbottom University of Agriculture, Technology and Sciences, Prayagraj, Uttar Pradesh, India

${ }^{3}$ Centre of Food Technology, Faculty of Science, University of Allahabad, Prayagraj, Uttar Pradesh, India priyanka.singh.29@gmail.com
\end{abstract} \\ https://doi.org/10.34302/crpjfst/2020.12.5.10

\begin{tabular}{ll}
\hline Article history: & ABSTRACT \\
Received: & The aim of the present study was to evaluate the nutritional, anti-nutritional, \\
29 August 2020 & antioxidant, antimicrobial and prebiotic activity in peels of four selected \\
fruits (apple, sweet lime, papaya and banana) commonly consumed in India. & The nutritional and anti-nutritional constituents along with antioxidant \\
\multicolumn{1}{c}{ 25 December 2020 } & activities were determined. Anti-bacterial activity and prebiotic potential of \\
Keywords: & selected fruit peels was also estimated. All the selected fruit peels exhibit \\
Fruit peels; & good nutritional value along with acceptable level of anti-nutritional factors. \\
Antioxidant; & The highest values of antioxidant activity, total phenolics and flavonoids \\
Antimicrobial; & were recorded in peels of banana and apple. The results indicate that peels \\
Prebiotic potential. & of different fruits can be regarded as natural plant source of antioxidants with \\
& high prebiotic potential.
\end{tabular}

\section{Introduction}

Historically fruits have been recommended as a significant necessity of human diet and are extensively recommended for their healthpromoting benefits. Worldwide, India is the second largest consumer and producer of fruits and generates million tons of fruit waste per year affecting as a solid waste (Patel and Goyal, 2012; Pathak et al, 2017). The organized sectors concerned with fruit processing, packaging, distribution and consumption in Philippines, China, United States of America and India generates approximately 55 million tones of fruit wastes which are dumped in landfills causing environmental hazards (Wadhwa and Bakshi, 2013).

These fruit peels can be utilized for many purposes as they are loaded with nutrients instead of disposing them and causing environmental hazards. The outer protective layer of a fruit commonly known as peel, rind or skin provides mechanical support to fruits. In botanical terms the outermost layer of the fruit is epicarp or exocarp which forms the outer tough skin of the fruit mainly composed of cellulosic material along with other components like pigments (flavonoids,

carotenoids, chlorophylls), enzymes, fattyacids, essential oils, triterpenoids, steroids, bitter principles (limonin) and waxes. Different fruit peels contains significant amount of polyphenols, dietary fiber, polyunsaturated fatty acids, proteins, essential amino acids and potassium.

The peel of the fruits also exhibits good prebiotic potential due to presence of nondigestable fiber compounds and stimulate the growth of beneficial bacteria of large bowel system which decrease the infectious episodes. The most superior form of prebiotics is Galactooligosaccharides (GOS) belonging to a group of particular nutrient fibers. Consumption of fruits either raw or processed provides considerable proportion of the whole antioxidant in the diet. According to researches, fruit peels are the foundation of many other biological functions along with the prevention of many chronic diseases such as anti-cancer, antidiabetic, anti-hypertensive, anti-aging and antiinflammatory (Ke et al, 2015). Preliminary research has established other potential effects of prebiotic consumption such as reducing abdominal discomfort and bloating, boosting immune system, regulating weight management and maintaining bone mineral density along with improving brain health (Patel and Goyal, 2012).

Fruit peels are usually considered as a waste and represent an environmental problem by most of the industries as their disposal becomes a serious problem. On the other hand many studies have been carried out about the potential utilization of several fruit peels originated byproducts for their inclusion in the daily diet of humans as this can reduce industrial costs and provide correct solution for the pollution problem by justifying the new investments in equipments connected with broadest applications in pharmaceuticals, alcoholic beverages, food processing and textile industries (Kumar et al, 2018). Peel waste contains a biomass-rich material such as lignocelluloses, which stimulate new pathways for the production of low cost, sustainable and renewable adsorbents for water treatment applications. (Bhatnagar et al., 2015) 
Peels of some widely consumed fruits like apple, sweet lime, papaya and banana represents a great therapeutic potential as they are highly rich in vitamins, minerals and antioxidants. They can be easily utilized to produce variety of value added products such as organic acids, prebiotics, polysaccharides, enzymes, ethanol, single cell protein, bioactive compounds, natural fertilizers and pollution repellents. Overall, fruit peels possess numerous pharmacokinetic and pharmacodynamics properties and its constituents are widely utilized for many clinical and therapeutic applications.

Apple peel (Malus pumila) are dense source of nutrients and it's a powerhouse for health, due to presence of high antioxidant content, pectins, phytochemicals (phenol and flavonoids), fiber, vitamins $A$ and $C$, minerals like potassium, calcium, phosphorus, iron and folate.

Sweet lime (Citrus limetta) peels are rich in active phytochemicals that can protect health. It provides ample amount of pectin, folic acid, potassium and vitamin C. Citrus species contributes in preventing life threatening diseases (Gorinstein et al., 2004).

Papaya peel (Carica papaya L.) exhibits high antioxidant activity by scavenging free radicals and prevents life threatening chronic diseases like diabetes, cancer cardiac diseases (John and Shahidi, 2010). It is a good source of phenolic compounds, minerals and fibre.

Banana peel (Musa Acuminata) contains significant amount of lignin, protein, fiber, starch, vitamin $\mathrm{C}$, pyridoxine, potassium and magnesium. It is equally dense in antioxidant luetin, which enhance and protects eye and cardiac health.

The objective of the present investigation was to evaluate the nutritional composition, antioxidant capacity, prebiotic potential and anti-microbial property of four different fruit peels (apple, sweet-lime, papaya and banana) by using in-vitro methods.

\section{Material and Methods}

\subsection{Procurement of fruits}

The required fruits of apple, sweet lime, papaya and banana were collected from a local fruit market and were stored in cold conditions until the moment of analysis. Other raw materials were purchased from the licensed and authorized shops.

\subsection{Samples preparation}

Healthy mature fruits were selected free from bacterial infection and mechanical damages. The fruits were peeled, cleaned and dried at $60 \pm 5^{\circ} \mathrm{C}$ for $12 \mathrm{~h}$ in hot air oven, ground and stored in airtight polythene bags for further analysis

\subsection{Chemicals}

Standards of gallic acid and quercetin were purchased from Sigma-Aldrich (St. Louis, MO, USA). 2,2'-diphenyl-1-picrylhydrazil (DPPH) and Folin-Ciocalteau's reagent were obtained from Fluka (United Kingdom). All the other reagents were of analytical grade.

\subsection{Gross chemical composition}

Moisture, ash, crude protein, crude fat, fibre and total carbohydrate content of fruit peels were estimated according to the methods of AOAC (2000).

\subsection{Determination of minerals}

In $1 \%$ hydrochloric acid, the ash samples were dissolved and the solutions were used for the determination of the following minerals: Iron, calcium, potassium and phosphorus according to the methods of AOAC (2000).

\subsection{Determination of anti-nutritional factors}

The phytic acid content was determined by the colorimetric method reported by Wheeler and Ferrel (1971) and the optical density is read at $480 \mathrm{~nm}$, by using a spectrophotometer. Phytic acid solution was used to obtain a standard curve.

Tannins were determined by the method given by Marigo (1973) and the optical densities were measured at $700 \mathrm{~nm}$. The formula used to estimate the tannic acid content is given below:

$$
\text { Tannic acid } \%=\frac{\text { mg of Tannic acid } \times \text { dilution } \times 100}{\text { mg of sample taken of colordevelopment }}
$$$$
\times \text { Weight of samplex1000 }
$$

Oxalic acid were estimated by volumetric analysis (titration method) given by Adeiyi et al., 2009. The following formula was used to obtain the oxalate $\%$.

\section{$\%$ Oxalate}

titre value $\times$ M of KMnO4 $\times$ vol. makeup $\times$ molecular wt. of oxalate $\times 100$ aliquot taken for titration $\times$ wt. of sample $\times 1000$

\subsection{Extract Preparation}

$150 \mathrm{~g}$ of different fruit peels powder was dissolved in $300 \mathrm{ml}$ of organic solvent (ethanol) in conical flask and incubated at room temperature at $150 \mathrm{rpm}$ (rounds per minute) for two days. Filtered with Whatman No.1 filter paper and concentrated to dryness at $40-60{ }^{\circ} \mathrm{C}$ on hot water bath to get the semi solid crude extracts which were stored at $4{ }^{\circ} \mathrm{C}$ in airtight bottles till further use.

\subsection{Determination of percentage yield}

The percentage yield was evaluated by comparing the weight of fresh whole fruit and 
dried powder of peel obtained from the same amount of fruit.

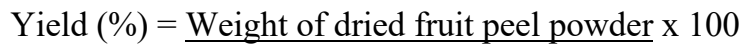

Weight of fresh fruit

\subsection{Determination of Total Phenol Content}

The total phenolic content was estimated by the Folin-Ciocalteu method using standard phenolic compound gallic acid as described by (Singleton and Rossi, 1965) with some modification. $1 \mathrm{ml}$ of aliquot (extract or standard solution of gallic acid) (20,40,60, 80 and $100 \mathrm{mg} / \mathrm{L}$ ) was taken in a test tube was diluted with $9 \mathrm{ml}$ of nanopure water. $1 \mathrm{ml}$ of FolinCiocalteu reagent was combined to the mixture and vortexed. It was allowed to react for $5 \mathrm{~min}$ then $10 \mathrm{ml}$ of $7 \% \mathrm{Na}_{2} \mathrm{CO}_{3}$ solution was added with constant mixing. Immediately the solution was diluted to volume $25 \mathrm{ml}$ with nanopure water and was thoroughly mixed and incubated for $90 \mathrm{~min}$ in darkness at $23^{\circ} \mathrm{C}$. The absorbance verses prepared blank was measured at $750 \mathrm{~nm}$ and the obtained results of total phenols were expressed as mg gallic acid equivalents (GAE; $\mathrm{mg} / 100 \mathrm{~g}$ fresh mass).

\subsection{Determination of Total flavonoid content}

The total flavonoids content was estimated by the method described by Sakanaka et al, (2004). The standard solution was prepared by dissolving $10 \mathrm{mg}$ of quercetin in $10 \mathrm{ml}$ of methanol to obtain $1000 \mu \mathrm{g} / \mathrm{ml}$ solution. Different concentration of aliquots $(6.25,12.5$, $25,50,80$ and $100 \mu \mathrm{g} / \mathrm{ml}$ ) was prepared from stock solution in 6 different test tubes. Each sample was mixed with $1.5 \mathrm{ml}$ of methanol, $0.1 \mathrm{ml}$ of $10 \%$ aluminium chloride, $0.1 \mathrm{ml}$ of $1 \mathrm{M}$ potassium acetate solution followed with $2.8 \mathrm{ml}$ of distilled water and the reaction mixture was mixed well and left at room temperature for 30 min. The absorbance of the resulting solution was measured immediately at $415 \mathrm{~nm}$ against the sample blank which was prepared in similar way by replacing aluminium chloride with distilled water. The results of samples were expressed as mg of quercetin equivalents of total dried fractions. All the fractions were run in triplicate. For the preparation of test solution $10 \mathrm{mg}$ of extract was dissolved in $10 \mathrm{ml}$ of methanol to get $1 \mathrm{mg} / \mathrm{ml}$ solution. The required volume of the above solution was transferred into the test tubes and the color development was carried out as for the standard. The absorbance of the test solution was measured at $415 \mathrm{~nm}$ against blank in a double beam spectrophotometer (Perkin Elmer). In the extract the total flavonoid content was expressed as $\mu \mathrm{g} / \mathrm{ml}$. In the test sample the concentration of total flavonoid content was calculated from the calibration curve by plotting absorbance verses concentration.

The calibration curve was prepared by using different concentrations of quercetin which is expressed in $\mathrm{mg} / \mathrm{gm}$ dry weight.

\subsection{Determination of Antioxidant activity}

The free radical scavenging activity was measured by using the 1,1- diphenyl-2picrylhydrazyl (DPPH) assay (Brand-Williams et al., 1995) with some modifications. The preparation of stock solution was done by dissolving $2.15 \mathrm{mg}$ of DPPH in $1.65 \mathrm{ml}$ methanol. The test tube was covered with aluminum foil to protect it from light and stored at $20^{\circ} \mathrm{C}$ until required. For control reading $150 \mu \mathrm{DPPH}$ was added to $3000 \mu \mathrm{l}$ methanol and immediately absorbance was taken at $517 \mathrm{~nm}$. Different concentrations $\left(10-50 \mu \mathrm{g} \mathrm{ml}^{-1}\right)$ of the extract as well as standard compound (ascorbic acid) were taken and the volume was made uniformly to $150 \mu \mathrm{l}$ with methanol. Each sample was further diluted with methanol upto $3 \mathrm{ml}$ and to each 150 $\mu 1$ DPPH was added. The reaction mixture was allowed to stand in dark for $15 \mathrm{~min}$ at room temperature, methanol was used as blank and the absorbance was recorded at $517 \mathrm{~nm}$ spectrophotometrically. The concentration of sample required to scavenge $50 \%$ of DPPH radical ( $\mathrm{IC}_{50}$ value) was noted by linear regression analysis of dose response curve plotting between percentage inhibition and concentration.

The percentage of scavenging activity was calculated using the following formula:

$\%$ Scavenging $=[$ (Absorbance control Absorbance sample)/Absorbance control] $\times 100$

\subsection{Determination of anti-bacterial property}

The agar cup-plate diffusion method was used to analyze the antibacterial activity of the prepared methanolic extracts of apple, sweetlime, papaya and banana peels. The crude extracts were diluted in 100\% Dimethyl Sulphoxide (DMSO) at a concentration of 25, 50,70 and $100 \mathrm{mg} / \mathrm{mL}$ respectively. $20 \mathrm{ml}$ of sterile nutrient agar medium was poured into sterile petri-dishes and was allowed to solidify. The prepared medium was seeded by pour plate method with the micro-organisms using $4 \mathrm{ml}$ of sterile top agar containing $1 \mathrm{ml}$ culture. On the agar plate, wells $(6 \mathrm{~mm})$ were made by using sterile cork borer No. 4. The different concentrations of $(25 \mathrm{mg} / \mathrm{ml}, 50 \mathrm{mg} / \mathrm{ml}, 70$ $\mathrm{mg} / \mathrm{ml}, 100 \mathrm{mg} / \mathrm{ml}$ ) peel extracts were loaded into the wells and all the plates were incubated overnight at a temperature of $37^{\circ} \mathrm{C}$ for 24 hours with appropriate positive and negative controls. The drug tetracycline was used as a positive control in a concentration of $10 \mu \mathrm{g} / \mathrm{mL}$ and 100 $\%$ (DMSO) was used as negative control. The 
antibacterial activity of the peel extract was analyzed by measuring the diameter of the inhibition zone in $\mathrm{mm}$ with a transparent scale. The antibacterial assay for each of the extracts against all microorganisms tested was performed in triplicates.

Analysis of relative percentage (\%) zone of inhibition

The relative percentage zone of inhibition of two extracts of apple, sweet-lime, papaya and banana peels against four bacterial strains was calculated by formula:

Percentage relative zone of inhibition in $\mathrm{mm}=$

Zone of inhibition of sample (Plant extract)-Zone of inhibition of negative control $\times 100$

\subsection{Determination of Prebiotic Potential}

The prebiotic potential of different fruit peels were analysed according to the method given by Hussein et al., 2015. Three strains viz. L. casei, L. rhamnosus and L. plantarum were used to determine the prebiotic activities of the apple peel extract $(500 \mathrm{mg} / \mathrm{ml})$ and sweet lime peel extract $(500 \mathrm{mg} / \mathrm{ml})$ produced by crude extract method. The prebiotic activity was expressed as the 'prebiotic index'. This index relates the growth intensities of the probiotics with that of the pathogen E. coli.

Prebiotic Index

Optical Density of the growth of probiotic culture optical density of growth of E coli

\section{Control $=$}

Optical Density of the probiotics without extract optical Density of E.Coli without extract

\subsection{Statistical analysis}

The experimental data collected was tabulated and analyzed statistically with the help of approved statistical techniques (Imran and Coover, 1983). Percentage, mean scores, standard deviation (SD) of three replicates was analysed using the application available for Microsoft Excel (XLSTAT 2016). Significant differences among the samples were calculated using one-way ANOVA followed by Duncan's multiple range test at the 5\% level (p B 0.05).

\section{Results and discussions}

Nutritional profiling of different fruit peels (apple. sweet-lime, papaya and banana) were studied additionally studying the antioxidant activities, anti-microbial property and prebiotic potential of these peel extracts.

\subsection{Nutritional profiling}

Nutritional profile of the four different peels were analysed by determining its moisture, ash, protein, fat, carbohydrate, energy, fibre and minerals. In Table 1, data summarizes the proximate composition and mineral content of the different fruit peels. Papaya peel had the highest moisture content $88.62 \%$ followed by banana peel $87.94 \%$, apple peel $82.60 \%$ and sweet lime peel with a value of $73.60 \%$. The high moisture level in all the investigated samples suggests that the fruit peels cannot be stored for long duration and it can be easily spoiled. Higher water activity in fruit peels will increase the microbial action and bring about food spoilage. Jenson (1978) reported that around $85 \%$ of moisture content is present in fruits and vegetables. The banana peel had maximum $(12.33 \pm 0.15 \mathrm{~g} / 100 \mathrm{~g})$ ash content whereas apple peel had minimum $(1.48 \pm 0.02$ $\mathrm{g} / 100 \mathrm{~g})$. The high ash content indicates the amount of inorganic elements (potassium, calcium, copper, zinc and magnesium) present in fruit peels (Igile et al., 2013). The apple peel had the maximum amount of fat content $(8.73 \pm 0.11$ $\mathrm{g} / 100 \mathrm{~g})$ followed by sweet-lime $(7.76 \pm 0.11$ $\mathrm{g} / 100 \mathrm{~g})$, banana $(6.43 \pm 0.07 \mathrm{~g} / 100 \mathrm{~g})$ and papaya $(6.23 \pm 0.01 \mathrm{~g} / 100 \mathrm{~g})$. The fruit peels are low in fat content; therefore it can be used in product formulation especially for weight reduction diets. The protein content for the fruit peels varied different species, falling within the extremes of higher value $(8.7 \pm 0.17 \mathrm{~g} / 100 \mathrm{~g})$ in sweet-lime and lower value $(2.74 \pm 0.05 \mathrm{~g} / 100 \mathrm{~g})$ in apple. Parni and Verma (2014) reported that crude protein content in the peel of Carica papaya is $5.03 \mathrm{mg} / \mathrm{g}$. The carbohydrate and energy content was high in sweet-lime peel $(59.56 \pm 0.75 \mathrm{~g} / 100 \mathrm{~g}$ and $342.97 \pm 4.30$ $\mathrm{Kcal} / 100 \mathrm{~g})$ while papaya peel had minimum carbohydrate and energy content $(23.92 \pm 0.39$ $\mathrm{g} / 100 \mathrm{~g}$ and $164.9 \pm 16.34 \mathrm{Kcal} / 100 \mathrm{~g})$. The presence of complex carbohydrates especially natural sugars, fibre and starches in fruit peels. Anhwange et al. (2009) and Osarumwense et al. (2013) estimated that significant amount of carbohydrate was present in Banana and citrus peels.

The crude fibre content $(29.52 \pm 0.02$ $\mathrm{g} / 100 \mathrm{~g}$ ) was high in banana peel, which aids in better digestion and softens the stools resulting in prevention of constipation (Ayoola and Adeyeye, 2009).

The mean concentration of iron, calcium and phosphorus in the different fruit peels ranged $18.8 \pm 0.26$ to $33.4 \pm 0.2 \mathrm{mg} / 100 \mathrm{~g}, 14.45 \pm 0.50$ to $169.3 \pm 3.60 \mathrm{mg} / 100 \mathrm{~g}$ and $10.13 \pm 0.30$ to $83.0 \pm 0.52 \mathrm{mg} / 100 \mathrm{~g}$ with banana peel having the highest concentration of iron $(33.4 \pm 0.2$ $\mathrm{mg} / 100 \mathrm{~g})$ and sweet-lime peel having the highest concentration of calcium $(169.3 \pm 3.60$ $\mathrm{mg} / 100 \mathrm{~g})$ and phosphorus $(83.0 \pm 0.52 \mathrm{mg} / 100 \mathrm{~g})$. All these metals are usually related with plants 
or plant products. It was indicated from the results that fruit peels can supplement the body with some important macro and micro nutrients required by the body.

Table 1. Chemical composition and minerals content of different fruit peels

\begin{tabular}{|l|c|c|l|l|}
\hline $\begin{array}{c}\text { Chemical Composition } \\
\text { (g/100g) }\end{array}$ & $\begin{array}{c}\text { Apple } \\
\text { (Malus pumila) }\end{array}$ & $\begin{array}{c}\text { Sweet-lime } \\
\text { (Citrus limetta) }\end{array}$ & $\begin{array}{c}\text { Banana } \\
\text { (Musa acuminata) }\end{array}$ & $\begin{array}{c}\text { Papaya } \\
\text { (Carica papaya) }\end{array}$ \\
\hline Moisture (\%) & $82.60 \pm 0.73$ & $73.6 \pm 0.42$ & $87.94 \pm 5.62$ & $88.62 \pm 0.77$ \\
\hline Ash (g) & $1.48 \pm 0.02$ & $4.6 \pm 0.1$ & $12.33 \pm 0.15$ & $11.5 \pm 0.3$ \\
\hline Fat (g) & $8.73 \pm 0.11$ & $7.76 \pm 0.11$ & $6.43 \pm 0.07$ & $6.23 \pm 0.01$ \\
\hline Protein (g) & $2.74 \pm 0.05$ & $8.7 \pm 0.17$ & $8.68 \pm 0.07$ & $7.27 \pm 0.05$ \\
\hline Carbohydrate (g) & $53.01 \pm 0.34$ & $59.56 \pm 0.75$ & $45.67 \pm 5.87$ & $23.92 \pm 0.39$ \\
\hline Energy (Kcal) & $301.6 \pm 56$ & $342.97 \pm 4.30$ & $274.33 \pm 25.02$ & $164.9 \pm 26.34$ \\
\hline Fibre (g) & $12.3 \pm 0.05$ & $15.16 \pm 0.05$ & $29.52 \pm 0.02$ & $10.5 \pm 0.25$ \\
\hline \multicolumn{7}{|c|}{ Mineral content (g/100mg) } & $23.83 \pm 0.35$ \\
\hline Iron (mg) & $23.93 \pm 0.23$ & $18.8 \pm 0.26$ & $33.4 \pm 0.2$ & $15.56 \pm 0.30$ \\
\hline Calcium (mg) & $14.45 \pm 0.50$ & $169.3 \pm 3.60$ & $17.73 \pm 1.15$ & $20.46 \pm 0.25$ \\
\hline Phosphorus (mg) & $75.4 \pm 0.1$ & $83.0 \pm 0.52$ & $10.13 \pm 0.30$ & \\
\hline
\end{tabular}

\subsection{Anti -nutritional Profiling}

The most abundant anti-nutritional factors present in selected fruit peels (viz. oxalate, phytate and tannin) are shown in Table 2. The highest oxalate level $(247.00 \pm 5.89 \mathrm{mg} / 100 \mathrm{~g})$ was observed in banana peel followed by apple peel $(85.36 \pm 0.05 \mathrm{mg} / 100 \mathrm{~g})$ and sweet lime peel $(55.6 \pm 0.1 \mathrm{mg} / 100 \mathrm{~g})$. Papaya peel had the lowest oxalate level $(43.42 \pm 0.66 \mathrm{mg} / 100 \mathrm{~g})$. Oxalate can bind to different minerals present in food thus rendering them inaccessible for normal biochemical and physiological role such as blood coagulation, nerve impulse transmission, cofactor in enzymatic reaction, maintenance of teeth and bone Ladeji (2004). The obtained values of different fruit peels were below the established toxic level.

The phytate content in different fruit peels range from $5.5 \pm 0.2 \mathrm{mg} / 100 \mathrm{~g}$ in papaya peel to $251.66 \pm 7.63 \mathrm{mg} / 100 \mathrm{~g}$ in sweet lime peel.
Phytate forms an indigestible complex with different mineral elements (iron, calcium, magnesium, phosphorus, zinc and managanese), thus decreasing the absorption and bioavailability of these minerals (Umaru et al., 2007).

The maximum tannin content was observed in apple peel $(75.34 \pm 0.05 \%)$ while lowest values were observed in banana peel $(42.3 \pm 0.2 \%)$. The astringent taste in fruit peels was imposed by tannins which reduce the food intake and affects the palatability. Tannins also bind together enzymes of the digestive tract along with endogenous and exogenous proteins, therefore affecting the protein utilization (Sotelu et al., 1995). All the above mentioned fruit peels contains lower amounts of anti-nutrients, consequently they are recommended for consumption.

Table 2. Concentration of anti-nutritional factors in selected fruit peels

\begin{tabular}{|l|l|l|l|l|}
\hline Anti-nutritional Factor & \multicolumn{1}{|c|}{$\begin{array}{c}\text { Apple } \\
\text { (Malus pumila) }\end{array}$} & $\begin{array}{c}\text { Sweet-lime } \\
\text { (Citrus limetta) }\end{array}$ & $\begin{array}{c}\text { Banana } \\
\text { (Musa acuminata) }\end{array}$ & $\begin{array}{c}\text { Papaya } \\
\text { (Carica papaya) }\end{array}$ \\
\hline Oxalate (mg/100g) & $85.36 \pm 0.05$ & $55.6 \pm 0.1$ & $247.00 \pm 5.89$ & $43.42 \pm 0.66$ \\
\hline Phytate (mg/100g) & $146.66 \pm 11.54$ & $251.66 \pm 7.63$ & $7.27 \pm 0.24$ & $5.5 \pm 0.2$ \\
\hline Tannin \% & $75.34 \pm 0.05$ & $67.28 \pm 0.32$ & $42.3 \pm 0.2$ & $54.33 \pm 0.15$ \\
\hline
\end{tabular}

\subsection{Antioxidant Activity}

The total phenolic and flavonoid content in the different fruit peels was quantified in Table 3 .

The total phenolic contents exhibited in different fruit peels range from $3.04 \pm 0.02$ in papaya peel to $25.1 \pm 0.1 \mathrm{mg} / \mathrm{g}$ GAE in banana peel. Thus, results show that fruit peel of banana had a highest TPC content. The presence of phenolic in fruit peels explains the potential of antioxidant activity. These phenolic compounds react with phosphomolybdate and 
phosphotungstic acid contained in the FolinCiocalteu reagent undergoes complex oxidationreduction reactions (Kaur and Kapoor, 2011). The total phenolic content was expressed as milligrams of gallic acid equivalent per gram of dry weight (mg GAE/g DW).

According to Sir Elkhatim (2018) fruit peels are the readily available inexpensive source of bioactive compounds (natural antioxidant) and it contains high phenolic compounds than those in pulps. The total flavonoid content varied from $9.03 \pm 0.01$ in banana peel to $26.43 \pm 0.01 \mathrm{mg}$ quercetin equivalent/g of extract powder in apple peel. Apple peel showed the highest level of total flavonoid content, followed by sweetlime peel and papaya peel, while banana peel presented the lowest. Research findings suggest that fruit peels are good source of flavonoids and it possess excellent radical scavenging activity Sir Elkhatim (2018). According to Wanpeng et al., 2017 highest phenolic and flavonoid content was found in fruit peels followed by whole fruit and seeds whereas juice lowest phenolic content was seen in juices.

Table 3.Total phenol and flavonoid content in different parts of fruit peels

\begin{tabular}{|l|l|l|l|l|}
\hline \multicolumn{1}{|c|}{ Phytochemicals } & \multicolumn{4}{c|}{ Fruit peels } \\
\cline { 2 - 5 } & \multicolumn{1}{|c|}{$\begin{array}{c}\text { Apple } \\
\text { (Malus pumila) }\end{array}$} & $\begin{array}{c}\text { Sweet-lime } \\
\text { (Citrus limetta) }\end{array}$ & $\begin{array}{c}\text { Banana } \\
\text { (Musa acuminata) }\end{array}$ & $\begin{array}{c}\text { Papaya } \\
\text { (Carica papaya) }\end{array}$ \\
\hline Total Phenol (mg/g) & $11.60 \pm 0.04$ & $14.42 \pm 0.08$ & $25.1 \pm 0.1$ & $3.04 \pm 0.02$ \\
\hline Flavonoid (mg/g) & $26.43 \pm 0.01$ & $19.26 \pm 0.20$ & $9.03 \pm 0.01$ & $15.01 \pm 0.01$ \\
\hline
\end{tabular}

Total phenolic and total flavonoid were expressed as gallic acid equivalents (GAE) and rutin equivalents (RE), respectively

In this study in vitro antioxidant assay was performed to evaluate the antioxidant potential of different fruit peels. The most widely used method for assessing the antioxidant activity is scavenging model of DPPH radical. Table 4 displayed the antioxidant activity of different fruit peels. The DPPH values ranged from $10.71 \pm 0.03$ to $77.5 \pm 0.80 \mathrm{mg} / \mathrm{g}$. The highest value was found for banana peel, whereas the lowest was found for sweet-lime peel. The higher antioxidant activity in different fruit peels is due to the higher content of polyphenols and flavonoids. Sir Elkhatim (2018) reported that in three types of citrus fruit peels the antioxidant activity is significantly $(p<.05)$ higher than that in pulp and seeds.

The antioxidant capacity can also be studied by a simple method known as FRAP assay (Pulido et al. 2000). The FRAP values in different fruit peels varied from $15.17 \pm 0.14$ to $60.65 \pm 0.32 \mathrm{mg} / \mathrm{g}$. Apple peel had the highest FRAP value, whereas sweet-lime peel had the lowest FRAP value. According to Wanpeng et al., (2017) fruit peels had the higher FRAP values than other tissues like seeds, whole fruit and juice.

Table 4. Antioxidant activity of different fruit peels

\begin{tabular}{|l|l|l|l|l|}
\hline Antioxidant & \multicolumn{1}{|c|}{$\begin{array}{c}\text { Apple } \\
\text { (Malus pumila) }\end{array}$} & $\begin{array}{c}\text { Sweet-lime } \\
\text { (Citrus limetta) }\end{array}$ & $\begin{array}{c}\text { Banana } \\
\text { (Musa acuminata) }\end{array}$ & $\begin{array}{c}\text { Papaya } \\
\text { (Carica papaya) }\end{array}$ \\
\hline DPPH (mg/g) & $75.31 \pm 0.08$ & $10.71 \pm 0.03$ & $77.5 \pm 0.80$ & $57.3 \pm 0.02$ \\
\hline FRAP (mg/g) & $60.65 \pm 0.32$ & $15.17 \pm 0.14$ & $20.5 \pm 0.2$ & $26.13 \pm 0.97$ \\
\hline
\end{tabular}

\subsection{Antibacterial activity}

Antibacterial potential of the peels were checked against gram positive and gram negative pathogenic bacteria by using different concentration of ethanolic extracts for all the fruit peels.

Table 5. Antibacterial activity of apple, banana, Papaya and sweet-lime peel extracts indicated by Zone of inhibition (250mg dry $\mathrm{wt} / \mathrm{ml}, \mathrm{mm}$ )

\begin{tabular}{|c|c|c|c|c|c|}
\hline Peel & Extract & $\frac{\text { Escherichia. }}{\underline{\text { Coli }}}$ & $\underline{\text { Pseudomonas }}$ & $\underline{\text { Shigella }}$ & $\frac{\text { Staphylococcus. }}{\text { Aureus }}$ \\
\hline & Aqueous & $24.33 \pm 1.15^{\mathrm{d}}$ & $16.93 \pm 0.11^{\mathrm{d}}$ & $15.03 \pm 0.15^{\mathrm{a}}$ & $26.8 \pm 0.26^{\mathrm{c}}$ \\
\hline \multirow{2}{*}{ Apple } & $\begin{array}{c}50 \% \\
\text { ethanol }\end{array}$ & $23.7 \pm 0.17^{\mathrm{d}}$ & $18.16 \pm 0.15^{\mathrm{e}}$ & $16.33 \pm 0.57^{\mathrm{b}}$ & $26.96 \pm 0.057^{\mathrm{c}}$ \\
\hline $\begin{array}{c}70 \% \\
\text { ethanol }\end{array}$ & $30.93 \pm 0.11^{\mathrm{f}}$ & $19.66 \pm 0.57^{\mathrm{f}}$ & $19.9 \pm 0.1^{\mathrm{d}}$ & $30.33 \pm 0.57^{\mathrm{d}}$ \\
\hline Squeous & $20.16 \pm 0.15^{\mathrm{c}}$ & $15.06 \pm 0.11^{\mathrm{c}}$ & $17.13 \pm 0.15^{\mathrm{c}}$ & $40.66 \pm 0.57^{\mathrm{c}}$ \\
\hline & $50 \%$ & $21.16 \pm 0.28^{\mathrm{c}}$ & $10.23 \pm 0.20^{\mathrm{a}}$ & $20.1 \pm 0.17^{\mathrm{d}}$ & $43.3 \pm 0.26^{\mathrm{d}}$ \\
\hline
\end{tabular}




\begin{tabular}{|c|c|c|c|c|c|}
\hline & ethanol & & & & \\
\hline & $\begin{array}{c}70 \% \\
\text { ethanol }\end{array}$ & $26.3 \pm 0.26^{\mathrm{e}}$ & $14.06 \pm 0.11^{b}$ & $23.1 \pm 1.74^{\mathrm{e}}$ & $45.93 \pm 0.11^{\mathrm{e}}$ \\
\hline \multirow[t]{3}{*}{ Banana } & Aqueous & $20.2+0.25^{\mathrm{c}}$ & $19.3 \pm 0.47^{f}$ & $19.7 \pm 0.35^{d}$ & $21.3 \pm 0.50^{\mathrm{b}}$ \\
\hline & $\begin{array}{c}50 \% \\
\text { ethanol }\end{array}$ & $20.2 \pm 0.11^{\mathrm{c}}$ & $20.3 \pm 0.20^{f}$ & $20.1 \pm 0.05^{\mathrm{d}}$ & $21.5 \pm 0.30^{b}$ \\
\hline & $\begin{array}{c}70 \% \\
\text { ethanol }\end{array}$ & $22.3+0.25^{\mathrm{c}}$ & $21.3 \pm 0.47^{\mathrm{g}}$ & $21.6 \pm 0.35^{d}$ & $22.6 \pm 0.50^{b}$ \\
\hline \multirow[t]{3}{*}{ Papaya } & Aqueous & $15.5 \pm 0.87^{\mathrm{a}}$ & $10.1 \pm 0.05^{\mathrm{a}}$ & $18.3 \pm 0.05^{\mathrm{c}}$ & $18.3 \pm 0.25^{\mathrm{a}}$ \\
\hline & $\begin{array}{c}50 \% \\
\text { ethanol }\end{array}$ & $16.2 \pm 0.36^{a}$ & $10.5 \pm 0.37^{\mathrm{a}}$ & $19.2 \pm 0.11^{\mathrm{d}}$ & $18.6 \pm 0.11^{\mathrm{a}}$ \\
\hline & $\begin{array}{c}70 \% \\
\text { ethanol }\end{array}$ & $18.3 \pm 0 .^{\mathrm{b}}$ & $11.3 \pm 0.05^{\mathrm{a}}$ & $20.3 \pm 0.05^{\mathrm{d}}$ & $20.3 \pm 0.25^{\mathrm{a}}$ \\
\hline
\end{tabular}

Each value represents the mean and standard deviation from three lots;

Means with different superscripts for each sample are significantly different $(p<0.05)$

It is evident from the results (Table 5) that highest zone of inhibition was observed for $70 \%$ ethanolic extract of sweet-lime peel $(45.93 \mathrm{~mm})$ and $70 \%$ ethanolic extract of apple peel $(30.33 \mathrm{~mm})$ against_S.aureus . Substantial zone of inhibition was observed for $70 \%$ ethanolic extract of sweet-lime peel against Shigella $(23.1 \mathrm{~mm})$ and E.coli $(26.3 \mathrm{~mm})$. The overall data clearly states that $70 \%$ ethanolic extract of all the peels manifests good anti-bacterial potential. All the extracts showed inhibition in following sequence S.aureus $>$ Ecoli>
S.flexneri $>$ Pseudomonas. According to Ghai et al (2018) sweet lime has shown maximum zone of inhibition for Bacillus cereus (9mm) > Escherichia coli $>(7.67 \mathrm{~mm})$ Enterobacter aerogenes $(8.33 \mathrm{~mm})>\quad$ Pseudomonas aeruginosa $(4.67 \mathrm{~mm})$. The citrus fruit peel extract using Citrus sinensis (orange), Citrus limon (lemon), and Citrus limetta (sweet lime) also showed high antimicrobial activity against the common gastrointestinal pathogens (Nisha et al., 2013) (fig 1).
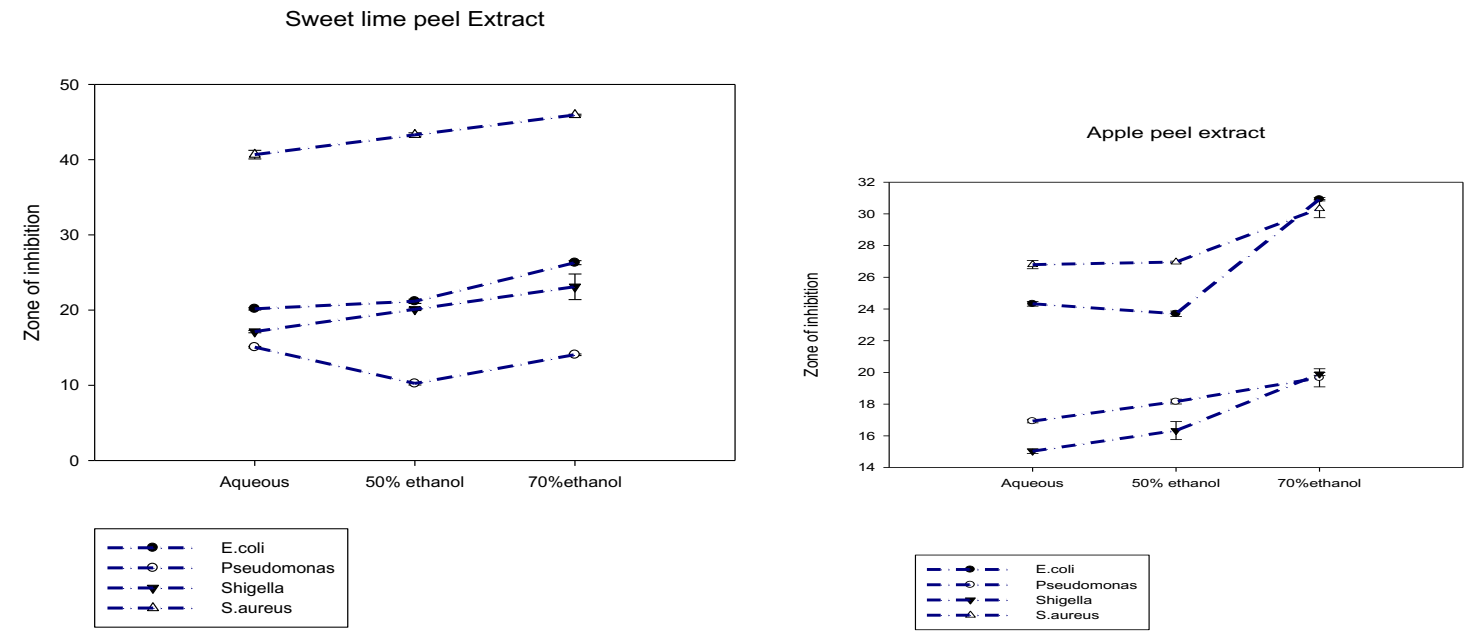

Papaya peel extract
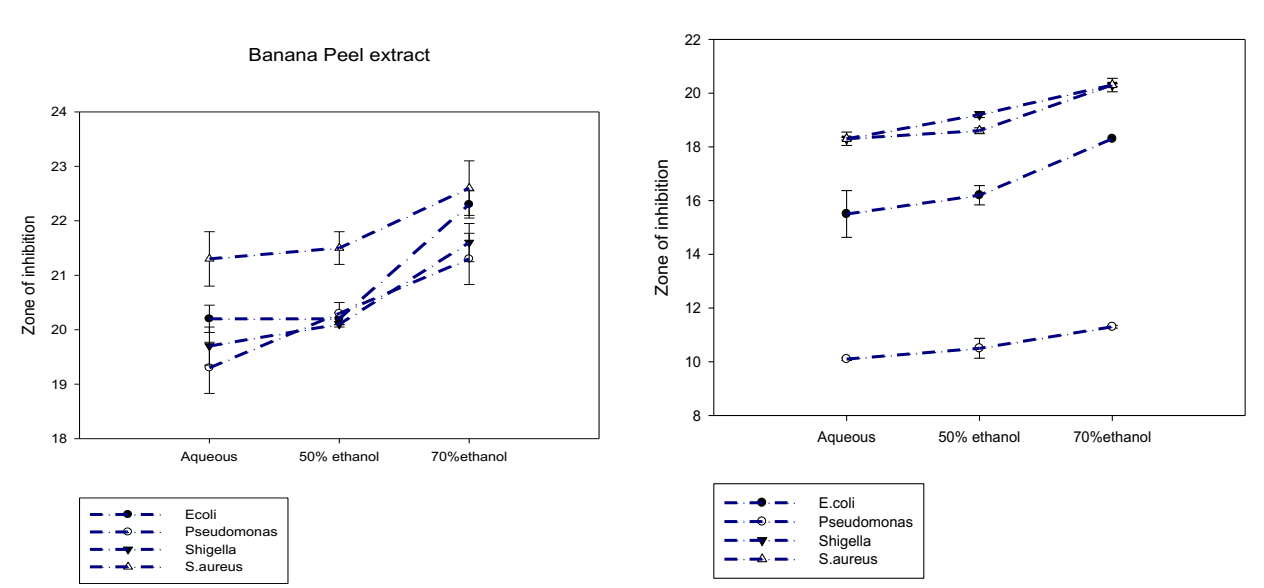

Figure 1. Antibacterial activity of fruit peels extracts indicated by Zone of inhibition 
The above data indicates the least concentration at which clear zone of inhibition against bacterial strains was observed. All active extracts characterized by MIC values as equal to or higher than $50 \mathrm{mg} / \mathrm{ml}$. Aqueous extracts of both the peels have shown the higher values of MIC as $250 \mathrm{mg} / \mathrm{ml}$ and $175 \mathrm{mg} / \mathrm{ml}$ for apple and sweet lime respectively. 70\% ethanolic extract of apple and sweet-lime peel extract shows the clear zone of inhibition at lowest concentration.

Table 6. MIC of apple, banana, Papaya and sweet-lime peel extracts

\begin{tabular}{|c|c|c|c|c|c|}
\hline Peels & Extracts & $\frac{\text { Escherichia. }}{\text { coli }}$ & Pseudomonas & Shigella & $\frac{\text { Staphylococcus. }}{\text { Aureus }}$ \\
\hline \multirow{3}{*}{ Apple } & Aqueous & $250 \mathrm{mg} / \mathrm{ml}$ & $250 \mathrm{mg} / \mathrm{ml}$ & $250 \mathrm{mg} / \mathrm{ml}$ & $175 \mathrm{mg} / \mathrm{ml}$ \\
\hline & $\begin{array}{c}50 \% \\
\text { ethanol }\end{array}$ & $175 \mathrm{mg} / \mathrm{ml}$ & $175 \mathrm{mg} / \mathrm{ml}$ & $175 \mathrm{mg} / \mathrm{ml}$ & $50 \mathrm{mg} / \mathrm{ml}$ \\
\hline & $\begin{array}{c}70 \% \\
\text { ethanol }\end{array}$ & $150 \mathrm{mg} / \mathrm{ml}$ & $150 \mathrm{mg} / \mathrm{ml}$ & $150 \mathrm{mg} / \mathrm{ml}$ & $50 \mathrm{mg} / \mathrm{ml}$ \\
\hline \multirow[t]{3}{*}{$\begin{array}{l}\text { Sweet } \\
\text { Lime }\end{array}$} & Aqueous & $175 \mathrm{mg} / \mathrm{ml}$ & $175 \mathrm{mg} / \mathrm{ml}$ & $250 \mathrm{mg} / \mathrm{ml}$ & $175 \mathrm{mg} / \mathrm{ml}$ \\
\hline & $\begin{array}{c}50 \% \\
\text { ethanol }\end{array}$ & $50 \mathrm{mg} / \mathrm{ml}$ & $50 \mathrm{mg} / \mathrm{ml}$ & $175 \mathrm{mg} / \mathrm{ml}$ & $50 \mathrm{mg} / \mathrm{ml}$ \\
\hline & $\begin{array}{c}70 \% \\
\text { ethanol }\end{array}$ & $20 \mathrm{mg} / \mathrm{ml}$ & $50 \mathrm{mg} / \mathrm{ml}$ & $50 \mathrm{mg} / \mathrm{ml}$ & $20 \mathrm{mg} / \mathrm{ml}$ \\
\hline \multirow[t]{3}{*}{ Banana } & Aqueous & $250 \mathrm{mg} / \mathrm{ml}$ & $500 \mathrm{mg} / \mathrm{ml}$ & $500 \mathrm{mg} / \mathrm{ml}$ & $250 \mathrm{mg} / \mathrm{ml}$ \\
\hline & $\begin{array}{c}50 \% \\
\text { methanol }\end{array}$ & $250 \mathrm{mg} / \mathrm{ml}$ & $500 \mathrm{mg} / \mathrm{ml}$ & $500 \mathrm{mg} / \mathrm{ml}$ & $250 \mathrm{mg} / \mathrm{ml}$ \\
\hline & $\begin{array}{c}70 \% \\
\text { methanol }\end{array}$ & $175 \mathrm{mg} / \mathrm{ml}$ & $250 \mathrm{mg} / \mathrm{ml}$ & $250 \mathrm{mg} / \mathrm{ml}$ & $175 \mathrm{mg} / \mathrm{ml}$ \\
\hline \multirow[t]{3}{*}{ Papaya } & Aqueous & $500 \mathrm{mg} / \mathrm{ml}$ & $750 \mathrm{mg} / \mathrm{ml}$ & $750 \mathrm{mg} / \mathrm{ml}$ & $250 \mathrm{mg} / \mathrm{ml}$ \\
\hline & $\begin{array}{c}50 \% \\
\text { methanol }\end{array}$ & $500 \mathrm{mg} / \mathrm{ml}$ & $500 \mathrm{mg} / \mathrm{ml}$ & $500 \mathrm{mg} / \mathrm{ml}$ & $175 \mathrm{mg} / \mathrm{ml}$ \\
\hline & $\begin{array}{c}70 \% \\
\text { methanol }\end{array}$ & $250 \mathrm{mg} / \mathrm{ml}$ & $500 \mathrm{mg} / \mathrm{ml}$ & $500 \mathrm{mg} / \mathrm{ml}$ & $125 \mathrm{mg} / \mathrm{ml}$ \\
\hline
\end{tabular}

\subsection{Prebiotic Activity}

Three strains viz. L.casei, L. rhamnosus and L. plantarum were used to determine the prebiotic activities of the apple peel extract $(500 \mathrm{mg} / \mathrm{ml})$ and sweet lime peel extract $(500 \mathrm{mg} / \mathrm{ml})$ produced by crude extract method. The prebiotic activity was expressed as the 'prebiotic index'. This index relates the growth intensities of the probiotics with that of the pathogen $E$. coli. The results recorded in Table 7 indicate that both the extracts enhanced the growth of probiotic culture. The prebiotic index for Lactobacillus plantarum was greater for apple peel as compared to sweet-lime peel. The prebiotic index for Lactobacillus rhamnosus was greater for sweet-lime peel as compared to apple peel. The prebiotic index for Lactobacillus casei was almost equal for apple peel and sweetlime peel.

Table 7. Prebiotic Index of apple and sweet-lime peels

\begin{tabular}{|l|c|c|c|}
\hline \multirow{2}{*}{ Extracts } & \multicolumn{3}{|c|}{ Prebiotic Indices using various Probiotics } \\
\cline { 2 - 4 } & L.plantarum & L.rhamnosus & L. casei \\
\hline Apple Peel & 25.55 & 16.88 & 33.55 \\
\hline Sweet Lime Peel & 20.46 & 21.11 & 33.48 \\
\hline Papaya Peel & 2.91 & 1.17 & 0.976 \\
\hline Banana Peel & 4.32 & 1.19 & 1.29 \\
\hline Control & 0.80 & 0.98 & 1.04 \\
\hline
\end{tabular}

\section{Conclusions}

The obtained results revealed that peels of different fruits are dense in medicinally important health-promoting nutrients and it is an excellent source of natural antioxidants which enhance the bioavailability of bioactive compounds. The methanolic extract of different fruit peel extracts shows greater resistance against the number of pathogenic microorganisms. Fruit peels are the natural source of prebiotics with its potential applications as functional food ingredients or as natural preservatives. The extracts from these fruit peels could be a good source in designing 
the useful drugs or pharmaceutical products for human health.

\section{References}

Anhwange, A.; Ugye, T.J.; Nyiaatagher, T.D. (2009). Chemical composition of Musa sapientum (banana) peels. Electronic Journal of Environmental, Agricultural and Food Chemistry, 8, 437-442.

AOAC. 2000. Official methods of analysis. 17th ed. Official Methods of Analysis of AOAC International. Gaithersburg (MD): CAB publisher.

Ayoola, P. B. and Adeyeye, A. (2009). Proximate Analysis and Nutrient Evaluation of Some Nigerian Pawpaw Seeds Varieties, Science Focus, 14(4), 554-558.

Bhatnagar, A.; Sillanpää, M.; Witek-Krowiak, A. (2015) Agricultural waste peels as versatile biomass for water purification - A review. Chemical Engineering Journal, 270, 244-271.

BrandWilliams,W.; Cuvelier, M.E.; Berset, C. (1995) Use of a free radical method to evaluate antioxidant activity LebensmittelWissenschaft und-Technologie, 28 (1) , 2530 .

Ghai,S.; Goel,S.; Mittal,H.; Katoch, S.; and Vashisht, S.(2018) Antibacterial activity of fruit peels against bacterial isolates. Global journal of Bioscience and Biotechnology. 7(4), 570-574.

Hussein, M.D.M.; Ghaly, M.F.; Osman, M.Y.; Shalaby, A.G.; Helal, M.M. (2015). Production and prebiotic activity of exopolysaccharides derived from some probiotics. Egyptian Pharmaceutical Journal , 14, 1-9.

Jenson, N.F., (1978). Wild Plant fruit production: A Research symposium on Wild Food Plants, Number 32, 1-5.

John, J.A.; Shahidi, F.(2010) Phenolic compounds and antioxidant activity of Brazil nut (Bertholletia excels). Journal of functional foods, 2, 196-209.

Ke, Z.; Pan, Y.; Xu, X.; Nie, C.; Zhou, Z. (2015) Citrus Flavonoids and Human Cancers. Journal of Food and Nutrition Research, 3(5), 341-351.

Kumar, V.; Sharma, V.; Singh, L. (2018) Pectin from fruit peels and its uses as pharmaceutical and food grade: a descriptive review. European journal of biomedical and pharmaceutical sciences, 5(5),185-199.

Ladeji, O.; Akin, C.U., Umaru, H.A. (2004). Level of antinutritional factors in vegetables commonly eaten in Nigeria. African Journal Of Natural Sciences www.ajns.org.ng > ojs. 7, 71-73.

Marigo, G.(1973) Sur une méthode de fractionnement et d'estimation des composés phénoliques chez végétaux. Analusis.2,106-110.
Nisha, S.N.; Swedha, A.A. and Rahman, J.S.N. (2013) Antibacterial activity of Citrus sinensis peel against enteric pathogens. International journal of pharmaceutical resarch and bio science. 2(5), 1-13.

Osarumwense, L.O.; Okunrobo, E.G.; Uwumarongie-ilori (2013). Phytochemical screening, proximate and elemental analysis of Citrus sinensis peels (1.) Osbeck, Journal of Applied Sciences and Environmental Management, 17, 47-50.

Parni, B.; Verma, Y. (2014) Biochemical properties in peel, pulp and seeds of Carica papaya, Plant Archives, 14(1),565-568.

Patel, S. and Goyal, A. (2012) The current trends and future perspectives of prebiotics research. 3Biotech, 2, 115-12.

Pathak, P.D.; Mandavgane, S.A.; Kulkarni, B.D. (2017) Fruit peel waste: characterization and its potential uses, Current Science, 113 (3), 444- 454.

Pulido, R.; Bravo, L.; Saura-Calixto, F. (2000) Antioxidant activity of dietary polyphenols as determined by a modified ferric reducing/ antioxidant power assay. Journal of Agricultural and Food Chemistry, 48, 33963402

Sakanaka, S.; Tachibana, Y.; Okada, Y.(2005) Preparation and antioxidant properties of extracts of Japanese persimmon leaf tea (kakinoha-cha) Food chemistry, 89, 569575. doi: 10.1016/j.foodchem.2004.03.013

Singleton, V.L. and Rossi, J.A. (1965) Colorimetry of Total Phenolics with Phosphomolybdic-Phosphotungstic Acid Reagent. American Journal of Enology and Viticulture, 16, 144-158.

Sir Elkhatim, K.A.; Elagib, R.A.A.; Hassan, A.B. (2018) Content of phenolic compounds and vitamin $\mathrm{C}$ and antioxidant activity in wasted parts of Sudanese citrus fruits. Food Science \& Nutrition, 2018 Jul; 6(5), 12141219.

Umaru, H. A. ; Adamu, R.; Dahiru D. and Nadro M. S. (2007) Levels of antinutritional factors in some wild edible fruits of Northern Nigeria, African Journal of Biotechnology, Vol. 6 (16), pp. 1935-1938.

Wadhwa, M.; Bakshi, M.P.S. (2013) Utilization of fruit and vegetable wastes as livestock feed and as a substrate for generation of other value added products. In: Makkar, H.P.S.(Ed.). Food and Agriculture Organization of United Nations, RAP Publication 2013/04,p.56.

Wanpeng, Xi; Juanfang Lu; Junping Qun and Bining Jiao.(2017) Characterization of phenolic profile and antioxidant capacity of different fruit part from lemon (Citrus limon Burm.) cultivars Journal of Food Science and Technology, Apr; 54(5), 1108-1118. 
Wheeler, E.L.; Ferrel, R.E. (1971) A Method for phytic acid determination in wheat and wheat fractions. American Association of Cereal chemists 28, 313-320. 